\title{
Determinant Factors toward Exclusive Breast Feeding to Infants
}

\author{
La Jumu \\ Nursing School of Biak, Health Polytechnic of Jayapura, Jalan Petrus Kafiar, Riedge I, Biak, Papua, Indonesia
}

\begin{abstract}
The granting of exclusive breast milk in Indonesia reached only 67\% of the total babies. Based on Demographic and Health Survey Indonesia (SDKI) in 2006-2007 Purpose: To identify mother's milk knowledge factors, the myths of breastfeeding attitudes and support the husband with the giving breast milk excusive in area Public health center Biak Numfor Regency Town of Biak of Papua Province. Methods: the method of writing used in this research is the use of analytical design research with Cross Sectional approach. Cross sectional study design i.e. the measurement or observation is performed at a time. Results: from the results of research, Knowledge: $p=0.05$, not significantly $r=0.830$., (correlation mother's milk is high), the myth of : $p=-0.091$ (not significant)., $r=0,551$ (mother's milk are correlated)., the attitude of the $p=0.000$, (significant) $r=0,630$ (correlation mother's milk), and social support husband: $p=0.05$ (Significant), $r=0.289$ (correlated), in the granting of Exclusive breast milk. Conclusion; The knowledge of the respondents positively beneficial, the existence of the myth the less influential but influential for introspection and family., rewarding good positive attitude, positive social support beneficial husband against the granting of exclusive breast milk on the baby. suggestions : health workers and counselors of breast milk increases the longer the knowledge, attitudes and social supporting of husband in the granting of exclusive breast milk in infants as well as improve understanding of the context of myth against the granting of exclusive breast milk in infants in the region Multiply Public health center of the city.
\end{abstract}

Keywords: Knowledge, The myth of breast milk, Attitude, Husband's support, Exclusive Breast Milk

\section{Introduction}

Breast milk is one of the best food sources for babies because it has so many essential substances that are good to improve your immune (The nature of, 2013). Breastfeeding provides some advantages for infants, baby will be more healthy, intelligent and a good personality, besides breast milk contain substances immune diseases namely immunoglobulin, practical and easy to give it, as well as cheap and clean (Judarwanto, 2009). The Government through the Health ACT No. 36 of the year 2009 about giving breast milk (breast milk) Exclusively on Article 128 (1), Every Baby deserves a breast milk exclusively since born to 6 (six) months, except over the milk mother medical, (2) for the granting of breast milk, the family, the Government, local governments, and the public should support the baby's mother in full with the provision of time and special facilities, (3) provision of special facilities as referred to in paragraph (2) was held at the place of work and place of public facilities. While this fact shows based on the results of interviews with health workers in Public health centres of Biak Town in February 2014 at get 50 people to mother breastfeeding, 10 people giving exclusive breast milk until 6 months, 8 people give breast milk is accompanied give plain water and slurry, 7 others provide breast milk to 4 months accompanied by Ambon Bananas, 25 mothers not giving exclusive breast milk because the first month mothers give breast milk and next month given a milk bottle. Most mothers do not want to breastfeed her child because they prefer giving formula milk because it is more practical and also release some breastfeeding myths for abstinent food should not be eaten by the mother that is being breastfeeding. The husband often told his wife to go to the garden to work and a motherin-law who keep their children. Mothers need support from the husband in the granting of the right of mothers milk information so that mothers want to give breast milk exclusively and are able to withstand the influence of dairy promotion as well as the myths that exist. Breastfeeding myths, knowledge, attitudes and support her husband with the granting of exclusive breast milk in theory are related but in the territory of the town of Biak, relationship Health knowledge, breastfeeding myths, attitudes and support her husband with the granting of breast milk exclusive has yet to be explained.

Based on Demographic and Health Survey Indonesia (SDKI) in 2006-2007 are the granting of exclusive breast milk in Indonesia only covers $67 \%$ of the total babies. The percentage decreases with increasing age of the baby, that is, $54 \%$ in infants aged 2-3 months and 19\% in infants ages 7-9. More alarming, $13 \%$ of babies under two months have been given formula milk and one of three 2-3 months of age infants have been given extra food. Based on a survey of national health (Surkesnas) 2004 shows that maternal mortality (AKI) in Indonesia is 307 per 100,000 live births, whereas in PAPUA province is 554 per 100,000 live births. Infant mortality (AKB), national 52 per 1000 live births and in Papua Province is 62 per 1000 live births. (Aulia, 2009). In Papua, the prevalence of infant malnutrition reached 9.4 percent or higher than the national figure of just 5.4 percent. The prevalence of infant malnutrition is less in Papua achieve 24.2 percent or higher than national prevalence only 24.2 percent (Fernandez,2009). Based on data in a number of Cities Breed Baby Public health centres that year 2013 as much as 567 baby, the number of babies who are there, who got exclusive BREAST MILK as much as 266 (46.91\%) (Reports section of the nutrition field Public health centres Biak town, 2014).

Many factors influence a mother in breastfeeding exclusively to her baby, some research has been done in urban as well as rural areas in Indonesia and other developing Countries, 


\section{International Journal of Science and Research (IJSR) \\ ISSN (Online): 2319-7064}

Index Copernicus Value (2016): 79.57 | Impact Factor (2015): 6.391

showed that the support systems, knowledge of the mother against the giving breast milk exclusively, the promotion of infant formula and food additives have an influence on the practice of given exclusive breast milk itself. These influences can give a negative and a positive impact in smoothing the granting of exclusive breast milk (Santosa, 2004). As for the other factors influencing the awarding of breast milk is a factor in the socio-cultural economics (formal education of mothers, family income and work status of the mother), psychological factors (fear of losing the appeal of being a woman, inner pressure), physical factors (mother mom the pain, mastitis, and so on) lack of factors the role of community health workers got less illumination or encouragement about the benefits the granting of exclusive breast milk (Soetjiningsih, 1997). While according to Roesli (2004), revealed that the phenomenon of lack of granting of exclusive breast milk due to several factors, among them: the mother's knowledge about inadequate breast milk exclusively, an English myth is not good about giving breast milk exclusively, as well as a flurry of improvements in the conduct of the mother and in short the granting of maternity leave given by the Government against working mothers, are the reasons often expressed by mothers who are not successful breastfeeding exclusively. Additional feeding in infants aged 6 months < will have an effect on the health of the baby which causes indigestion which further lead to disorders of growth, which in turn could increase cases of malnutrition (Grahacendikia, 2013). Green in Notoatmodjo 2010 says the factors that affect a person's behavior is the predisposing factors manifest in knowledge, attitudes, beliefs, and values, the probability factors manifest in the physical environment, the availability of facilities or health means, the driving factor that is manifest in the attitude and behavior of health workers or other officers.

Many consents done by the officers of the health centers, among others, given information mother's milk to mothers about giving exclusive breast milk but the results are not optimal. Besides attempts to increase the willingness of mothers to breastfeed is support from the husband. The husband can provide emotional support in the form of increased attention and concern on the mother's husband. Other solutions provide motivation milk mother to the Public health centre not to stop giving information to the mother's milk to mother about giving exclusive breast milk and continue disseminating the benefits of breast milk.

\section{Method of Research}

\section{Research Design}

Design research is something that is very important in the research that allows maximize control for several factors that can affect the mother's milk is a product of accuration. In line with (great, 2011) that: design research is something that is very important in the research that allows the maximum control some factors that could affect the accuration mother's milk is an outcome.

This research use analytic design with cross sectional approach. Cross sectional study design i.e. the measurement or observation is performed at a time (once upon a time) (Moral and Suyanto, 2015).

\section{Population, Sample, large sample and Sampling}

Mother's milk is popular whole objects or objects that are explored (Notoatmojo, 2010). Populair the milk of mothers in this study are mothers breast-feeding in the region of the town of Biak Public health centres a number of 50 nursing mothers. The sample is part of a mother's milk populair examined/most amount of characteristics shared by mother's milk (Kelana, 2011). The samples on this research has been defined that meets the criteria of inclusion as much as 45 respondents.

\section{Result}

The relationship of knowledge with the granting of exclusive breast milk

Table 4.1: Distributions of Data of knowledge related to the granting of Exclusive breast milk in the region of the town of

Biak public health centre Date 03-08 February 2015

\begin{tabular}{|c|c|c|c|}
\hline \multirow[t]{2}{*}{ Category } & \multicolumn{2}{|c|}{ The granting of exclusive breast milk } & \multirow{3}{*}{$\begin{array}{c}\text { Total } \\
(\%)\end{array}$} \\
\hline & Not & Yes & \\
\hline Knowledge & $\mathrm{N}(\%)$ & $\mathrm{N}(\%)$ & \\
\hline Less & $22(48,9)$ & $0(0)$ & $22(48.9)$ \\
\hline Enough & $5(11.1)$ & $10(22.2)$ & $15(33.3)$ \\
\hline Good & $0(0)$ & $8(17.8)$ & $8(17.8)$ \\
\hline Total & $27(60)$ & $18(40)$ & $45(100)$ \\
\hline \multicolumn{4}{|c|}{$\begin{array}{l}\text { The results of statistical tests Spearman's Rho } \\
\qquad p=0.00, r=0.830\end{array}$} \\
\hline
\end{tabular}

Corresponding table 4.1 , it can be noted that the respondents with less knowledge categories, $22 \%$ of respondents are not providing breast milk exclusively. as for the respondent categories knowledge enough, $11.11 \%$ of respondents are not providing breast milk exclusively, and $22.22 \%$ respondents give breast milk exclusively. Moreover the respondent categories knowledge good, $17.77 \%$ of the respondents are giving breast milk exclusively. Analysis using statistical tests Spearman's Rho retrieved value $\mathrm{p}=0.000$, meaning the $\mathrm{H} 1$ is accepted. This shows that there is a significant relationship between knowledge with the granting of exclusive breast milk and the value of the coefficient in the can is $r=0.830$, meaning that there is a very high degree of relationship between knowledge by administering breast milk exclusive.

The myth of breastfeeding Relationship with the granting of exclusive breast milk

Table 4.2: Distribution of Data myth of Breastfeeding is associated with the giving breast milk exclusively in the territory of the town of Biak Public health centre Date 03-08

February 2015

\begin{tabular}{|c|c|c|c|}
\hline Category & The Granting Of Exclusive breast milk & \multirow{2}{*}{$\begin{array}{c}\text { Total } \\
(\%)\end{array}$} \\
\cline { 2 - 3 } & Not & Yes & N (\%) \\
\hline Myth & N (\%) & $9(20)$ & $20(44.4)$ \\
\hline Negative & $11(24.4)$ & $9(20)$ & $25(55.6)$ \\
\hline Positive & $16(35.6)$ & $18(40)$ & $45(100)$ \\
\hline Total & $27(60)$ & \multicolumn{2}{|c|}{$\begin{array}{c}\text { The results of statistical tests Spearman's } \text { Rho } \\
p=0,551, r=-0.091\end{array}$} \\
\hline \multicolumn{3}{|c}{} \\
\hline
\end{tabular}

Volume 6 Issue 12, December 2017 


\section{International Journal of Science and Research (IJSR) \\ ISSN (Online): 2319-7064}

Index Copernicus Value (2016): 79.57 | Impact Factor (2015): 6.391

Corresponding table 4.2, it can be noted that the respondents by category does not trust the mythical (negative), $24.44 \%$ of the respondents is not giving exclusive breast milk but $20 \%$ of respondents provide breast milk exclusively. As for the category of respondents believing the myth (positive), $35.55 \%$ of respondents are not providing breast milk exclusively and $20 \%$ respondents give breast milk exclusively.

Analysis using statistical tests Spearman's Rho retrieved value $p=0,551$ meaning that $\mathrm{H} 0$ is accepted. This shows that there is no significant relationship between knowledge with the granting of exclusive breast milk no correlation mother's milk $(r=-0.091)$.

The relationship of Attitude with the granting of exclusive breast milk.

Table 4.3: Data distribution of maternal Attitude associated with the giving breast milk exclusively in the territory of the town of Biak Public health center Date 03-08 February 2015.

\begin{tabular}{|c|c|c|c|}
\hline Category & \multicolumn{2}{|c|}{ The Granting of Exclusive breast milk } & Total \\
\cline { 2 - 3 } & Not & Yes & \\
\hline The attitude of the & $\mathrm{N}(\%)$ & $\mathrm{N}(\%)$ & \\
\hline Negative & $23(51.1)$ & $4(8.9)$ & $27(60)$ \\
\hline Positive & $4(8.9)$ & $14(31.1)$ & $18(40)$ \\
\hline Total & $27(60)$ & $18(40)$ & $45(100)$ \\
\hline \multicolumn{3}{|c|}{ The results of statistical tests Spearman's Rho } \\
$p=0.000, r=0.630$ \\
\hline
\end{tabular}

Corresponding table 4.3 , it can be noted that the respondents with negative attitude category, $51.1 \%$ of respondents are not giving exclusive breast milk but $8.8 \%$ of respondents provide breast milk exclusively. As for the respondents' category a positive attitude, $8.8 \%$ of respondents are not providing breast milk exclusively, and $31.11 \%$ respondents give breast milk exclusively.

Analysis using statistical tests Spearman's Rho retrieved value $\mathrm{p}=0.000$, meaning the $\mathrm{H} 1$ is accepted. This shows that there is a significant relationship between attitude with the granting of exclusive breast milk and the value of the coefficient in the can is $r=0.630$, meaning that there is a fairly high degree of relationship between attitude with the granting of exclusive breast milk.

Relationship with husband Support the granting of exclusive breast milk.

Table 4.4: The husband's social support Data distribution with giving breast milk Exclusively in the territory of the town of Biak public health center Date 03-08 February 2015.

\begin{tabular}{|c|c|c|c|}
\hline Category & The Granting of Exclusive breast milk & \multirow{2}{*}{$\begin{array}{c}\text { Total } \\
(\%)\end{array}$} \\
\cline { 2 - 3 } $\begin{array}{c}\text { Support The } \\
\text { Husband }\end{array}$ & $\mathrm{N}(\%)$ & $\mathrm{N}(\%)$ & \\
\hline Negative & $21(46.7)$ & $9(20)$ & $30(66.7)$ \\
\hline Positive & $6(13.3)$ & $9(20)$ & $15(33.3)$ \\
\hline Total & $27(60)$ & $18(40)$ & $45(100)$ \\
\hline \multicolumn{2}{|c|}{ The results of statistical tests Spearman's Rho } \\
$P=0.054 ., r=0.289$ \\
\hline
\end{tabular}

Corresponding table 4.4 , be aware that the respondents with negative husband support category, $46.66 \%$ of respondents are not giving exclusive breast milk but $20 \%$ of respondents provide breast milk exclusively. As for the category of respondents support positive husband, $13.33 \%$ of respondents are not providing breast milk exclusively, and $20 \%$ respondents give breast milk exclusively.

Analysis using statistical tests Spearman's Rho retrieved value $p=0,054$ meaning Ho accepted. This shows that there is no significant relationship between the husband's support with the granting of exclusive breast milk, as well as the mother's milk correlation is low $(r=0.289)$

\section{Discussion}

Based on the number the granting of exclusive breast milk in the region of the town of Biak Public health centre it is known that $60 \%$ of the respondents did not give breast milk exclusively, This is caused by the lack of support from husband $(67 \%)$, and the attitude of mothers who negatively to the granting of exclusive breast milk (60\%). Other factors that affect the granting of breast milk is education, based on the educational level, the majority of mother the provide exclusive breast milk with an educational background junior high school (49\%). According to Sukardjo (2009), education affects the way someone glances towards the self and its environment, because that will be different attitudes of respondents by level of education low, medium and high in doing an act health. Essences high educational level that is then expected level of knowledge of the individual concerned will increase, so will facilitate in receiving/adopt positive health behaviors. Description of the deliberations of the research as follows:

a) Knowledge, Based on the results of the Research ini, shows there is a significant relationship between knowledge with the granting of exclusive breast milk. Knowledge (knowledge), is the result of knowing, and this happens after people doing particular against an object sensing. Knowledge or cognitive domain is very important in shaping one's actions (overt behavior). There is less knowledge category with respondents, $49 \%$ of respondents are not providing breast milk exclusively. As for the factors that affect the knowledge is education (Notoadmodjo, 2010). As seen from the above data, the level of knowledge that led to the granting of exclusive breast milk is becoming fewer majorities (49\%), with an educational background of junior high school. The phenomenon of increased knowledge, a person is required to have a good education so that gets the knowledge that good anyway. Knowledge is a very dominant, it is important for the formation of an Act of a person's overt behaviour (Notoatmodjo, 20 and10). According to (Mechanik in Sukardjo, 2009) knowledge affects motivation, whereas according to the Notoatmodjo, 20 (10) knowledge is influenced by education, education itself is a process of changing attitudes and behaviour of someone or a Group of people in the process of maturity of people through efforts, teaching and training and the level of education is measured through Diplomas last owned. The statement is generally not directly proposing the the existence of a relationship that is 


\section{International Journal of Science and Research (IJSR) ISSN (Online): 2319-7064}

Index Copernicus Value (2016): 79.57 | Impact Factor (2015): 6.391

significant between the knowledge and the will mom gives breast milk exclusively.

b) Myth, Based on the results of the Research, this indicates that there is no significant relationship between the myth of breastfeeding with the granting of exclusive breast milk. Information is the source of the myth of the mother's milk that is actually wrong but thought to have been circulating from mother's milk generally to mother about something. Based on the data above, most of the respondents believed the myth (55.6\%) supported with less knowledge (48.9\%). Nursing mothers may actually be getting mother's milk informer is right about giving breast milk exclusively, but most informer not until the mother's milk. According to Hatta (2007) myth is barriers to normal breastfeeding action. Tradition or cultural background in the area of residence is also a factor that may affect the practice of breastfeeding exclusively (Diharjo, 1998). The mother's mental attitude in nursing behavior associated with the mother's milk of oriented cultural values. Based on the answers of the respondents in the questionnaire can be known that respondents embraced some of the myths still circulate in biak numfor like shouldn't eat ice baby as it causes colds, the mother should not be fed chili in lactation because will cause the breast milk and spicy baby diarrhea, as for a small percentage of respondents who believe the myth yet still give breast milk exclusively this can be caused by the experiences of mothers about breastfeeding. Myths in the eyes of the woman is according to Diana (2007) says women's experiences since childhood will influence the attitude and the appearance of women in relation to breastfeeding at a later date. A woman who in her family had a habit of feeding her baby on a regular basis then it will have a positive Outlook about breastfeeding in accordance with everyday life. On the study of 11 respondents $(24.4 \%)$ does not believe in the myth but does not provide exclusive breast milk it can be caused by lack of knowledge of respondents and lack of support from the husband. Lack of knowledge of breastfeeding from a mother's milk is even more generally it will cause many mothers today find that their mothers and grandmothers low knowledge about breastfeeding and not able to provide support against the granting of exclusive breast milk. (Notoatmodjo, 2010). Based on the assumptions of researchers as we know shared knowledge is part of the culture, and culture is manifested in attitude and behavior. The myth of breastfeeding relationship with the granting of exclusive breast milk is not significant because questions about the myth of breastfeeding in the questionnaires need to be added again in accordance with local culture.

c) The attitude, Based on the results of this research, showing that there is a significant relationship between attitude with the granting of exclusive breast milk. Attitude is a response or reaction that is still closed to a stimulus from a person or object (Allport, 1995). As seen from the above data shows that the respondents have a negative attitude, not giving exclusive breast milk (51\%), where the majority of the respondents $(49 \%)$ has the educational background junior high school and a positive attitude but gives no water exclusive mother milk $(8.9 \%)$ it can be caused by a lack of support from the husband. The influence of people who are considered important, someone who means we will create many special affects the formation of attitude towards something (Azwar, 2007). Attitude itself contains a factor of feeling and motivation. This means that the attitude toward certain objects will always be followed by a feeling that can be positive or negative and also pleasant or unpleasant. The attitude of the containing motivation, means an attitude has thrust for the individual to behave in particular against the object exposes itself. Damayanti, in Notoatmodjo (2010), is giving mother's milk motivate restriction that is determinant of human behavior. There is a human attitude is determined by whether or not there is whether or not the mother's milk of motivate in man that this is because every human behavior is always based on motivation. In this study there were $8.9 \%$ of respondents who are being negative but still give breast milk exclusively, based on the answers of the questionnaire the respondents in this case caused by the mother's knowledge and support a good husband. According to (Mechanik in Sarwono, 1997) knowledge affect motivation, while according to Notoatmodjo, (2010) knowledge is influenced by education. The assumption that is the existence of the relationship researchers positive among education and mother's milk to be motivated. The assumption that the attitude researcher nursing mothers, indirectly influenced by the knowledge and support of the husband.

d) Social support of husband, Based on the results of this research, showing that there is no significant relationship between the husband's support with the granting of exclusive breast milk. Support the husband has any relationship with the knowledge and attitude of mother in giving breast milk exclusively. From the above data indicates that respondents with the support of husband negative and provide exclusive breast milk (20\%), based on the respondent's answers in the questionnaire is due to good knowledgeable mother. From the data the author get the respondents with the support of a good husband but not giving exclusive breast milk $(13.3 \%)$ this is caused by a lack of information. Notoatmodjo (2010) mother's milk affect the sources of information knowledge either from the media or from people in relation to the human groups gives the possibility to be influenced and affected members. Social support of husbands in increasing knowledge of mothers about breast milk exclusively should be optimal because it can give you an idea and add to the knowledge of mothers about the importance of breast milk to an infant. According to Slamet (1995) States that a person's knowledge on the influence by external and internal factors. Internal factors include mental and physical health, social, intelligentsia, attention level, interests and talents, while external factor is the support of family, community, individual learning methods are. Based on the results of the research show the lack of support the husband $(66.7 \%)$ so that it can also affect the attitude of the mother in the giving breast milk exclusively, supported by the majority of the negative attitude of the mother $(60 \%)$ The phenomenon of posture according to Anthony (1999) that the establishment of an attitude not just happens except through a specific process, through constant social contact among individuals with other individuals nearby. In line with the cited by Notoatmodjo Suliha (2002) an attitude has not automatically manifest in an action, to materialize an attitude becomes a deed but there needs to be a supporting factor in the form of facilities and infrastructure are available. Based on the data

\section{Volume 6 Issue 12, December 2017}




\section{International Journal of Science and Research (IJSR) \\ ISSN (Online): 2319-7064}

Index Copernicus Value (2016): 79.57 | Impact Factor (2015): 6.391

of the respondents obtained the support of a good husband and giving exclusive breast milk (20\%), support a good husband like providing cost when mother and baby need care, usher's mother consultation mother's milk as well as provide support in the form of attention and praise are emotionally. Social support the existence of the husband according to Hasan in Notoatmodjo, (2010) describes the individual and social environment influence each other, mutually supportive family environment will influence the habits of each Member of the family about health.

\section{References}

[1] Agoes, Azwar dan Agoes Achdiat serta Agoes Arizal., 2013. Penyakit di Usia Tua., Penerbit : Buku Kedokteran., EGC., Jakarta.

[2] Arikunto Suharsimi. 2010. Prosedur Penelitian Suatu PendekatanPraktik, Edisi Revisi. Rineka Cipta Jakarta.

[3] Aspuah Siti, 2013. Kumpulan Kuesioner dan Instrumen Penelitian Kesehatan, cetakan : pertama. Penerbit : Muha Medika. Yogyakarta.

[4] Azwar Agus dan Jacob, 1996. Antropologi Kesehatan Indoensia. Jilid I Pengobatan Tradisional. EGC. Jakarta

[5] Badrujaman Aip, 2010. Sosiologi untuk mahasiswa Keperawatan, Edisi Revisi. Trans Info Media Jakarta.

[6] Capernito J. Lynda, 1995. Nursing diagnosis : Process and aplication. New York : McGraw Hill.

[7] Conrad, P. 2001. The Seciology of Health and llnes:CriticalPerspective.New York: Worth.[suatu kumpulan tulisan yang bagus yang membahas hubungan sosiologi, politik, ekonomi, dan gender dengan kedokteran modern

[8] Chriswell, 2001. Teori dan Paradigma Penelitian sosial, Penyunting : Agus Salim. Tiara Wacana Yogya. Yogyakarta.

[9] Depkes., 2010., Pemasaran sosial dalam promosi kesehatan., edisi : revisi. Penerbit : Rineka Cipta Jakarta.

[10] Foster George M dan Anderson Barbara Gallatin, 1986. Antropologi Kesehatan, Penerjemah : Priyanti Pakan Suryadarma, Meutia F. Hatta Swasono. Cetakan pertama. UI-Press. Jakarta.

[11]Freud.J. dan McGuire.M. 1999. Health, lllness and social body.englewood Cliffs, NJ:Prentice Hall. [suatu buku teks yang bagus, teerutama menggunakan data Amerika, membahas hubungan sosial penyakit].

[12] Gujarati R. Damodar, 2006. Dasar-dasar ekonometrika, Jilid 1. Alih Bahasa Julius Mulady, Erlangga Jakarta.

[13] Hidayat , 2009. Ilmu Perilaku Manusia, Pengantar Psikologi untuk tenaga kesehatan. Trans Info Media Jakarta.

[14] Hassan Anwar, (2010). Komunikair susu ibu Kesehatan sebagai penunjang Promosi Kesehatan., PT Rineka Cipta., Jakarta

[15] Jimung, Martinus. 2017. Antropologi kesehatan. Konsep dan aplikasi., cetakan Pertama., Penerbit : CV Trans Info Media Jakarta

[16] Kelana Kusuma Dharma, 2011. Medotologi Penelitian Keperawatan. Trans Info Media, Jakarta.

[17] Kevin White, 2009. In Introduction to the Sociology of Healt English language edition Published by SAGE Publication of London, Thousand Oaks New Delhi and
Singapore, penerjemah Achmad Fedyani Saifudin -Ed. 3 - 1 - Rajawali Pers, 2011 Jakarta.

[18] Korompis, Grace E.C., 2016. Organisair susu ibu dan \& Manajemen Kesehatan, Penerbit : Buku Kedokteran EGC Jakarta.

[19] Kresno Sudarti. 2010. Aspek Sosial Budaya Yang Berhubungan dengan Perilaku Kesehatan, Edisi Revisi. Rineka Cipta Jakarta.

[20]Malik, 2011. Metodologi Penelitian Kesehatan Masyarakat. Trans Info Media Jakarta.

[21] Manuaba, 2012. Obstetri dan Ginekologi Sosial, cetakan Pertama, Penerbit : CV. Trans Info Media., Jakarta.

[22] Marquis, Bessie L dan Huston Carol J, 2010. Kepemimpinan dan Manajemen Keperawatan, teori \& Aplikasi, edisi keempat, alih bahasa : Widyawati, dan Wilda Eka Handayani serta Fruriolina Ariani, Penerbit Buku Kedokteran EGC Jakarta

[23] Maryam et al., 2010., Buku Pandua bagi kader Posyandu Lansia., Cetakan : Pertama ., Penerbit : CV Tans Info Media., Jakarta.

[24] Mubarak Wahid Iqbal, 2009. Sosiologi untuk keperawatan Pengantar dan Teori. Salemba Medika, Jakarta.

[25] Narwoko J. Dwi, Bagong Suyanto, 2006. Sosiologi Teks Pengantar dan Terapan. Edisi kedua, Cetakan kedua. Kencana Prenada Media Group, Jakarta.

[26] Nasution dan Thomas, 2008. Buku Penuntun Membuat Tesis Skripsi Disertair susu ibu Makalah, Cetakan kedua belas. PT Bumi Aksara, Jakarta.

[27] Noorkasiani, Heryati, Rita Ismail, 2009. Sosiologi Keperawatan, cetakan I. EGC, Jakarta.

[28] Noorkasiani, Krisnanty, Sumartini, 2012., Sosiologi Kebidanan., CV. Trans Info Media., Jakarta.

[29] Notoatmodjo, Soekidjo., 2010. Promosi Kesehatan dalam kesehatan masyarakat., edisi : revisi. Penerbit : Rineka Cipta Jakarta.

[30] .............. 2010. Konsep Perilaku Kesehatan., edisi : revisi. Penerbit : Rineka Cipta Jakarta.

[31] Kresno, 2010., Pendekatan sistem sosial suatu kerangka analisis promosi kesehatan., edisi : revisi. Penerbit Rineka Cipta Jakarta.

[32] Hassan, 2010. Konsep Advokair susu ibu dalam Kesehatan., edisi : revisi. Penerbit : Rineka Cipta Jakarta

[33].............., 2010. Kemitraan dalam Promosi Kesehatan., edisi : revisi. Penerbit : Rineka Cipta Jakarta.

[34]Padila, 2013. Buku Ajar Keperawatan gerontik dilengkapi aplikair susu ibu kasus asuhan keperawatan gerontik, terapi modalitas, dan sesuai kompetensi standar., cetakan : pertama., Penerbit : Nuha medika Yogyakarta.

[35] Partino H.R. dan Sutoro, 2008. Statistika Inferensial, Edisi ketiga, cetakan ketiga. Pustaka Mahasiswa. Yogyakarta.

[36]Peterson, C. 1999. Sterss at Work: A Sociological Approach. New York: Baywood. [Suatu tinjauan kepustakaan sosio-psikologis tentang stres].

[37]Potter, Patricia A., 1996., Pengkajian Kesehatan ( Pocket Guide to Health Assessment)., Edisi : ketiga., Alhi Bahasa : Veldman Y.P. James., Penerbit : Buku Kedokteran Jakarta.,

\section{Volume 6 Issue 12, December 2017}




\section{International Journal of Science and Research (IJSR) \\ ISSN (Online): 2319-7064}

Index Copernicus Value (2016): 79.57 | Impact Factor (2015): 6.391

[38] Pratomo, Hadi., 2010., Prinsi-prinsip advokair susu ibu dalam promosi kesehatan., edisi : revisi. Penerbit : Rineka Cipta Jakarta.

[39] Purwoastuti, Walyani, (2015). Ilmu Obstetri \&Ginekologi Sosial untuk Kebidanan, Pustaka Baru Press., Yogyakarta.

[40]Rita Damayanti, 2010., Persepsi dalam promosi kesehatan., edisi : revisi. Penerbit : Rineka Cipta Jakarta.

[41] Sabarguna, Boy S. dan Nurman Irzan., 2009. Sistem Bantu Keputusan Klinis., cetakan : Pertama., Penerbit : UI Jakarta.

[42] Santoso, Singgih, 2010. Statistik Multivariat Konsep dan Aplikair susu ibu dengan SPSS, PT.Elex Media Komputindo. Jakarta.

[43] Sarafino,E.P, 1997.Health Psychology, Third Edition. New York. John Wiley \& Son.Inc.

[44] Sasongko, Adi., 2010. Promosi Kesehatan melalui Pengorganisasian dan pengembangan masyarakat., edisi : revisi. Penerbit : Rineka Cipta Jakarta.

[45] Siegler Eugenia L dan Whitney Fay W. 2000. NursePhysician Colaboaration. Care of Adults and The Elderly. Alih Bahasa : Indraty Secillia, Cetakan pertama. Buku kedokteran EGC, Jakarta.

[46] Singaribuan Masri dan Effendi Sofian, 2008. Metode Penelitian Survai, Cetakan ke sembilan belas. Pustaka LP3SE Indonesia. Jakarta.

[47] Smeet, B. 1994. Psikologi Kesehatan. Grasindo, Jakarta

[48] Su'adah. 2005. Sosiologi Keluarga. UMM, Malang.

[49] Sudijono Anas, 2008. Pengantar Statistik Pendidikan. RajaGrafindo Persada, Jakarta.

[50] Sugiono, 2002. Statistik untuk penelitian, Alfabeta : Bandung

[51]..........., 2006. Statistik untuk penelitian, Alfabeta : Bandung

[52] Susilo, 2012. Statistika \& Aplikair susu ibu Untuk Penelitian Ilmu Kesehatan. Trans Info Media. Jakarta.

[53] Susilo dan Limakrisna, 2012. Cermat menyusun kuisioner Penelitian Ilmu Keperawatan. Trans Info Media, Jakarta.

[54] Sutriono, 1980. Metodologi Research, Jilid I, Cetakan ke IX. Yayasan Peneribitan Fakultas Psikologi Universitas Gajah Mada Yogyakarta.

[55] Suyanto, 2011. Metodologi dan Aplikair susu ibu Penelitian Keperawatan, Muha Medika Jogyakarta.

[56] Sunyoto Danang, 2014. Analis Data Penelitian kesehatan dengan SPSS., cetakan : pertama., penerbit : Nuha Media Yogyakarta.

[57] Susila dan Suyanto, 2015. Metodologi Penelitian Croos sectional, kedokteran, keperawatan, kesehatan masyarakat, kebidanan, psikologi, ilmu gizi, farmasi, dan lain-lain.. cetakan kesatu., penerbit : Bossscript., Klaten.

[58] Syafrudin., Mariam., (2010)., Sosial Budaya Dasar untuk Mahasiswa Kebidanan., CV. Trans Info Media., Jakarta.

[59] Tafal, Zarfiel., 2010. Evaluair susu ibu Promosi Kesehatan., edisi : revisi. Penerbit : Rineka Cipta Jakarta.

[60] Trimelia, 2011. Asuhan Keperawatan Klien Isolair susu ibu Sosial, cetakan : Pertama., Penerbit : CV. Trans Info Media., Jakarta.
[61] https://joma.unri.ac.id/index.php/jom.psik/view/8258. dowload tanggal 25 - 3 - 2017. Hubungan dukungan sosial teman sebaya dengan kualitas hidup lansia.

[62] https://eprints.ums.ac.id/30908/naskah/publikasi-cd-pdf. dounload tanggal 26 Maret 2017. dukungan keluargakeaktifan- posynadu lansia.

[63] http://.www.academia.edu/15386309/efektivitas-metodedemonstrasi-berupa-eksperimen-sains-sederhana.

Dounwload tanggal 25 Maret 2017. Efektivitas metode demosntrair susu ibu berupa eksperimen sederhana.

[64] https:/www.scribd.com/doc/304055914/bab-1-5-mikshubungan-dukungan-keluarga-dengan keaktifan lansia. Douwnload tanggal 25 Maret 2017. dukungan sosial keluarga mengikuti kegiatan posyandu lansia.

[65] https://repository.uinjkt.oc.id/dspace/bitstream/1234567 89/24101/1/desi\%/20angraeni-fkip.sd/dukungan sosial kader posyandu lansia. Douwnload tanggal 25 Maret 2017 . 